\title{
SUKSESBELEWING VAN SENIORBESTUURDERS VAN 'N GROOT FINANSIEËLE INSTELLING
}

\author{
WJP LABUSCHAGNE \\ JC KOK \\ DPJ SMITH \\ Departement Opvoedkunde \\ Randse Afrikaanse Universiteit
}

\begin{abstract}
The success experience of a financial institutions senior management. No clarity exists either in literature or in practice regarding people's success experience. People often experience a dissonance between external success and internal fulfillment. Important components needed to experience success were identified from literature in order to determine in practice to what extent such components formed part of the success experience of a financial institution's senior management. Internal (intrinsic) and external (extrinsic) factors were identified as necessary factors in order to experience success in a balanced way. In this article the findings of senior management's success experience are reported. The research was conducted by means of qualitative and quantitative methodology from a Personal and Professional Leadership perspective.
\end{abstract}

\section{OPSOMMING}

Daar is onduidelikheid in die literatuur, en in die praktyk, oor wat presies die belewenis van sukses by mense is. Mense ervaar dikwels 'n dissonans tussen uiterlike sukses en innerlike vervulling. Belangrike komponente in die belewing van sukses is in die literatuur geidentifiseer en in die praktyk getoets om vas te stel tot welke mate interne (intrinsieke) en eksterne (ekstrinsieke) faktore deel uitmaak van die suksesbelewing van senior bestuur in 'n finansiële instelling. Beide stelle faktore is van belang om op ' $n$ gebalanseerde wyse sukses te kan beleef. In hierdie artikel word die bevindings ten opsigte van senior bestuur se suksesbelewing gerapporteer. Die navorsing is met behulp van kwalitatiewe sowel as kwantitatiewe metodologie vanuit Persoonlike en Professionele Leierskapsperspektief ondersoek.

\section{SYNOPSIS}

The purpose of this article is to identify the components of success from the literature and to test the components in practice to see to what extent each component forms part of the success experience of a financial institution's senior management. The result was evaluated from a Personal and Professional Leadership (PPL) perspective.

Attention was given to the concept 'success' by describing and explaining the concept. Possible Personal and Professional Leadership guidelines to experience success were investigated and recommendations made to the financial institution.

A quantitative and descriptive research strategy was followed. The primary research methods used in the study included a survey, word and concept analysis. A word and concept analysis of the word 'success' was undertaken, while a literature study was conducted, to investigate current data documented on the subject of success. A questionnaire was developed to determine the success experience of the senior managers of a financial institution. The data was analysed, compared and interpreted.

The most important findings of the study are as follows:

- From the literature study and the empirical results of the investigation it was found that success is not necessary prosperity or money. Although money can be an advantage it does not guarantee sustainable success.

- Success is not a single component, for example accomplishment or achievement. Success requires a holistic approach constituted by multiple components. From the literature, 31 components of success were identified. To experience true success, balance in terms of all the life dimensions is required.

- Three success factors were identified in this study. The first factor is about the "inside-out" success experience (intrinsic factor). The second factor is an "outside-in" success experience (extrinsic

Versoeke vir afskrifte moet gerig word aan: DPJ Smith, Departement

Menslikehulpbronbestuur, RAU Universiteit, PO Box 524, Aucklandpark, 2006 factor). Both factors must be acknowledged in success aspirations. The third factor is a PPL-factor. Taking action is a result of the "inside-out" factor. This component is calculated, well thought through and based on an awareness of who I am; where I'm going, and why I am going there. It also includes knowledge about my purpose in life, understanding my potential and realising my potensial. This action should further be built around the individual's character and principles.

- Success is primarily not happiness. Success and happiness is not a goal to be achieved but a by-product of that which is longed for.

- Success is not power or influence. You could achieve success by reaching a certain position at work and think that you have made it. This position does not indemnify you from an empty and unfulfilled feeling.

o Success is not achievement and cannot only be measured against achievement alone.

o Success is a journey. How do I use each day? Do I make the best of each opportunity? Do I see the opportunity around me? Do I take the necessary action?

- More than two thirds of the respondents' linked success with the realisation of their goals, the reaching of certain milestones, living in balance with their life dimensions.

- Respondents that are 37 and older are more inclined to experience success in their emotional life in contrast with those under 37 years.

- Very happy people are more inclined to experience success in terms of their social and emotional life than people that are fairly happy.

PPL, in conclusion, regarding the success experience of a financial institutions senior management, challenges the traditional understanding of success and brings the individual to an awareness with regards to the write picture of what success is, and points to the allignment of happiness, health relationships, emotions, goals, dreams and potential in order to achieve it. Although, there are as many definitions of success as there are people thinking about it, success in one 
area of your life does not mean overall success. Balance in all the different life dimensions of life is essential. You must know who you are, where you stand with yourself, what you would like to do and take the necessary steps to get there. All these aspects are based on the principles of Personal and Professional Leadership. The conclusion can be made that PPL can make an important contribution to experience success in a balanced way.

\section{Die probleem}

Daar is onduidelikheid in die literatuur, en ook in die praktyk, oor wat presies die belewenis van sukses by mense is. Vele mense klim die suksesleer om ten einde tot die besef te kom dat hulle leer teen die verkeerde muur geleun het. In hierdie artikel is 'n analise gemaak van die suksesbelewing by seniorbestuurders van 'n groot finansiële instelling. Indien die topbestuur inligting kan kry oor hulle seniorbestuurders se suksesbelewing, kan dit hulle in staat stel om hulle seniorbestuur individueel so te bestuur sodat dit hopelik kan lei tot verhoogde produktiwiteit, kreatiwiteit, spanwerk, verbeterde verhoudings, gelukkiger werknemers, persoonlike groei, verbeterde gesondheid en 'n gebalanseerde lewe.

Die basiese vrae wat gevra is, is: Wat is die onderliggende diepgaande behoefte by sulke seniorbestuurders? Hoe sien en beleef hulle sukses? Ervaar hulle persoonlike groei en kreatiwiteit? Is hulle hart en gees in dit wat hulle doen of is hulle vasgevang in iemand anders se prentjie van sukses? Vind hulle vreugde en balans tussen die lang werkure, druk en verantwoordelikheid wat van hulle vereis word?

\section{Doelstelling}

Die doel met hierdie artikel is om die komponente waaruit sukses bestaan vanuit die literatuur te bepaal en in die praktyk te toets om te peil in watter mate elke komponent deel vorm van sodanige seniorbestuurders se belewing van sukses. Die resultaat hiervan is aan die hand van 'n persoonlike en professionele leierskapperspektief van sukses beoordeel. Daar is beoog om in hierdie verband waardevolle inligting aan die finansiële instelling te verskaf ten einde hulle seniorbestuur beter te verstaan in terme van: personeelretensie, persoonlike ontwikkeling, bevordering, loopbaanbeplanning, toekomstige uitdagings, om balans in sy werknemers se lewensdomeine te ervaar, maar ook om nuwe seniorbestuur na die finansiële instelling te lok.

\section{Konsepverheldering}

Vier sentrale konsepte verskyn in hierdie artikel rondom die sukses-vraag naamlik: 'sukses', 'vervulling' en 'geluk' en 'PPL'. Die eerste drie genoemde konsepte kom later aan die woord. Dit is wel nodig om die vierde konsep 'PPL' eerste hier toe te lig.

\section{Persoonlike en Professionele Leierskap (PPL):}

Verskeie dissiplines het elk 'n eie perspektief op die mens. Onder hierdie dissiplines tel die psigologie, die filosofie, die sosiologie, die biologie en die teologie. Persoonlike en Professionele Leierskap het ook 'n eie perspektief op die mens.

Volgens Smith (2001, p. 2) kan Persoonlike en Professionele Leierskap gedefinieer word as: "'n Studie van die kontinue of voortgesette verbintenis van die mens tot geldige en funksionele: selfkennis; doelnastrewing; potensiaalrealisering; begrip van samewerking met en waardetoevoeging tot ander mense, in besonder naasbestaandes, uitgebreide familie, vriende, kollegas in werkverband en mense in die algemeen; professionele bekwaamheid, vaardigheid en doeltreffendheid, veral vir sover dit die-in-lyn-bring van die mensfaktor tot organisasiedoeltreffendheid behels."

As paradigma verwys die PPL-perspektief se uitgangspunt daarna dat die mens se optrede deur sy innerlike harmonie bepaal word.
Enige verandering van gedrag sal bepaal word deur 'n verandering van die persoon self (Brewis, 2000, p. 7). Covey (1992, pp. 42-43) verwys hierna as die "inside-out approach". Hierdie van binne-nabuite-benadering is ' $n$ proses van hernuwing gebaseer op natuurlike wette wat menslike groei en progressie voorafgaan en wat dan lei tot verantwoordelike onafhanklikheid en effektiewe interafhanklikheid. Hierdie benadering beteken dat die mens met hom/ haarself begin - sy diepste self, sy karakter, sy paradigmas, sy waardes en sy motiewe (Covey, 1992, p. 43).

In terme van leierskap wys Cashman (2000, p. 18) daarop dat dit nie moontlik is om die leier van die persoon te skei nie. Baie mense maak hierdie fout om leierskap te sien as 'n eksterne gebeurtenis. Mense is gekondisioneer om te fokus op die eksterne manifestering van leierskap (visie, charisma, inspirasie, kreatiwiteit, ens.). Leierskap is nie bloot iets wat mense doen nie, maar is wel 'n proses, ' $n$ intieme uitdrukking van wie ons is. Cashman (2000, p. 19) sluit by Covey (1992, p. 43) aan as hy sê: "As we learn to master our growth as a person, we will be on the path to mastery of Leadership from the Inside Out". Leierskap is die outentieke uitdrukking van die self wat waarde skep (Cashman, 2000, p. 20). Ons doelgerigte innerlike lewe kom tot uitdrukking en ons maak ' $n$ verskil vanuit onsself.

Soos wat ons beweeg na 'n meer vervulde lewe, vervang ons fokus op sin en doel ons enkelvoudige fokus op eksterne sukses sodat ons innerlike dinamiek wat sukses en vervulling ondersteun, na vore kan tree (Cashman, 2000, pp. 22-23). Persoonlike en Professionele Leierskap hou homself besig met die vrae: Wie is jy? Waarheen gaan jy? Hoekom gaan jy daarheen? Dit wil juis beklemtoon dat die mens 'n keuse-moontlikheid het. PPL wys op die mens se daaglikse dissonanse en wil die mens begelei tot: selfkennis deur bewusmaking en bewuswording; verstaan en realisering van die individu se potensiaal; doelnatrewing; verstaan en waardeer die krag van jou denke; leef vanuit jou kern; vernuwe jouself daagliks - elke dag 'n bietjie beter; bou beter verhoudings en word vertrouenswaardig; balans in al sy lewensdimensies. Hierdie PPL-perspektief is onderliggend en deurslaggewend in die skrywe van hierdie artikel.

\section{METODE}

\section{Deelnemers}

Die volle komplement (een honderd en sestig) seniorbestuurders van 'n bepaalde finansiële instelling is betrek as respondente. Hierdie bestuurders is versprei oor Suid-Afrika. Daar is op hierdie groep bestuurders besluit vanweë hulle tweede plek posisie in die vier-vlak leierskapband van die gegewe finansiële instelling. Hierdie groep seniorbestuurders het dus 'n aansienlike posisie en verantwoordelikheid binne die finansiële instelling en sou as suksesvol beskou kan word.

\section{Meetinstrumente}

Navorsingstrategie

'n Kwantitatiewe navorsingstrategie is aangewend met die klem wat val op die omvang van die probleem in die samelewing of die verband tussen twee of meer veranderlikes in 'n populasie. In sodanige gevalle is empiries-statisties kwantifiserende tipe navorsing gepas. Die meetinstrument word dan gebruik om die data in te win. Statistiese tegnieke word gebruik om die toepaslike verwerkings te doen. Die resultate het moontlike veralgemeningspotensiaal in die populasie waaruit die respondente kom (Smith, 1993, p. 31). Verder word daar van 'n beskrywende strategie gebruik gemaak om 'n sistematiese, feitlike en akkurate beskrywing van 'n situasie of 'n saak te gee, ter wille van beter verstaan, insig en ingeligtheid (Smith, 1993, p. $35)$. Goeie begrip, insig en kennis van sukses sal gevorm word.

\section{Navorsingsontwerp}

Om die suksesbelewing van 'n finansiële instelling se seniorbestuur te bepaal, is ' $n$ vraelys ontwerp op die basis van 
die literatuurstudie. Dit behels die formulering van vrae soos dit in Tabel 1 verskyn. 'n Likerttipe 5 punt skaal is gebruik. Die vraelys is in Afrikaans en Engels aan die respondente aangebied.

\section{Prosedure}

Vraelyste is aan die seniorbestuurders gestuur deur middel van die instelling se e-posstelsel. Alle respondente is gevra om anoniem te bly en hulle response op 'n harde kopie uit te druk en terug te stuur, direk aan die navorser deur middel van die interne possisteem. Anonimiteit van die respondente is hiermee ook gewaarborg.

\section{Statistiese ontleding}

'n Totaal van 73 vraelyste is binne die gestelde tyd teruggestuur. Hierdie totaal verteenwoordig 'n $45.6 \%$ respons. Vier vraelyste is na die spertyd ontvang en is buite rekening gelaat.

Die geslag van die respondente het verdeel as $76.7 \%$ (56 uit 73) mans en $23.3 \%$ (17) vroue. Die minimum ouderdom van die respondente is 26 en die oudste 57 met ' $n$ gemiddelde ouderdom van 41.82 . Van hierdie 73 is $79.5 \%$ (58) getroud, $6.8 \%$ (5) woon saam, $9.6 \%$ (7) is geskei en $4.1 \%$ (3) was nog nooit getroud nie. In terme van hulle hoogste opvoedkundige kwalifikasies het $19.4 \%$ (14) 'n Matriek- (graad 12) kwalifikasie of laer, 38.9\% (28) 'n Post Matriek-sertifikaat of diploma, 26.4\% (19) 'n Honneursgraad of gevorderde Diploma, 13.9\% (10) 'n Meestersgraad en $1.4 \%$ (1) 'n Doktorsgraad. Die respondente se huistaal is oorwegend Engels met $58.3 \%$ (42), $37.5 \%$ (27) is Afrikaans, $2.8 \%$ (2) 'n Indiese taal en $1.4 \%$ (1) IsiZulu. Die geloof-of godsdiensverdeling is hoofsaaklik Christen met 83.6\% (61) gevolg deur Hindu met 9.6\% (7) en Islam met 1.4\% (1). Die balans 5.5\% (4) het nie in een van die bogenoemde kategorieë geval nie. Die gemiddelde jare diens van die respondente was 12.4 jaar, met 1 jaar as die minimum en 37 jaar diens as die maksimum. 4.1\% (3) van die respondente verdien tussen R10, 001.00 en R15,000.00 per maand, $6.8 \%$ (5) verdien tussen R15,001.00 en R20,000.00, 32.9\% (24) verdien tussen R20,001.00 en R30,000.00 per maand, $52.1 \%$ (38) respondente verdien meer as R30,000.00 per maand terwyl 4.1\% (3) respondente geweier het om hierdie vraag te beantwoord. Die gemiddelde werksure per week is 51.68 uur, met 'n minimum van 10 uur en 'n maksimum van 80 uur. Die respondente is gevra om hulle lewe te oorweeg in terme van hoe gelukkig hulle deesdae is. $28.8 \%$ (21) het gesê hulle is baie gelukkig, $57.5 \%$ (42) dat hulle taamlik gelukkig is, $2.7 \%$ (2) was nie baie gelukkig nie en $11 \%$ (8) was glad nie gelukkig nie.

\section{Geldigheid}

'n Multi-orde faktor-analise is gebruik en die 'Principal Axis Factoring' (Ekstraksie metode) en die Varimax Rotasie met Oblimin en Kaizer se Normalisasie (Rotasie metode) het drie faktore opgelewer. Op die basis van hierdie bevindings is die instrument en die data wat ingesamel is aanvaar as geldig met verwysing tot suksesbelewing.

\section{RESULTATE}

Die eerste orde faktor-analise het 8 faktore gelewer in terme van die vraag: in watter mate vorm elkeen van die volgende vir $\mathrm{u}$ 'n deel van $\mathrm{u}$ belewing van sukses? Die Kaiser-Meyer-Olkin steekproef se geskiktheid het te laag op .681 getoets. 'n Tweede orde faktoranalise is vervolgens gedoen en net twee faktore is opgelewer.

Van die twee faktore bestaan die eerste uit 17 items, met 'n Cronbach-Alpha betroubaarheidskoëffisient van .8666. Die tweede faktor lewer 10 items met 'n Cronbach-Alpha betroubaarheidskoëffisient van .8666. Hierdie tellings was oortuigend vir die navorser om met verdere analise voort te gaan.

\section{Faktor 1 se gelyste 17 items}

1. (11.4) Die progressiewe realisering van waardige doelwitte.

2. (11.21) Vervulde verwagtinge.

3. (11.22) Prestasie ('Achievement').
4. (11.23) Verrigting ('Accomplishment').

5. (11.31) Vervulling.

6. (11.17) Lojaliteit teenoor medewerknemers.

7. (11.18) Volle waardering vir afgehandelde werk.

8. (11.19) Taktvolle dissipline.

9. (11.12) Werksekuriteit.

10. (11.13) Goeie werksvoorwaardes.

11. (11.16) Hulp met persoonlike probleme.

12. (11.9) Help ander om suksesvol te wees.

13. (11.7) Ken jou doel in die lewe.

14. (11.11) Interessante werk.

15. (11.15) 'n Gevoel van "in wees" op dinge.

16. (11.20) Werksbevrediging.

17. (11.28) Gesondheid

$\mathrm{Al}$ die bo-gelyste items het te make met intrinsieke waardes. Hierdie faktor is oorwegend ' $n$ van binne-na-buite-benadering tot sukses.

Faktor 2 se gelyste 10 items

1. (11.5) Die vermoë om jou begeertes te vervul.

2. (11.6) Rykdom.

3. (11.10) Goeie salaris.

4. (11.29) Materiële dinge.

5. (11.30) Erkenning.

6. (11.27) Prestige.

7. (11.26) Weelde.

8. (11.14) Promosie.

9. (11.24) Mag.

10. (11.25) Roem.

Bogenoemde items van faktor 2 het te doen met eksterne beloning. Hierdie benadering is oorwegend 'n van buite-nabinne-benadering tot sukses.

TABel 1

RANGORDE VAN SUKSESBELEWINGKOMPONENTE

\begin{tabular}{|c|c|c|c|}
\hline $\begin{array}{l}\text { Rang- } \\
\text { orde }\end{array}$ & $\begin{array}{c}\text { Vraag } 11 \\
\text { In watter mate vorm elkeen van die } \\
\text { volgende vir } \mathbf{u} \text { 'n deel van } \mathrm{u} \text { belewing } \\
\text { van sukses? }\end{array}$ & Gemiddeld & $\begin{array}{l}\text { Standaard- } \\
\text { afwyking }\end{array}$ \\
\hline
\end{tabular}

\begin{tabular}{|c|c|c|}
\hline 1. 23. Verrigting & 4.53 & .603 \\
\hline 2. 28. Gesondheid & 4.53 & .709 \\
\hline 3. 11. Interessante werk & 4.51 & .626 \\
\hline 4. 22. Prestasie & 4.51 & .626 \\
\hline 5. 7. Ken jou doel in die lewe & 4.48 & .603 \\
\hline 6. 32. Vervulling & 4.45 & .602 \\
\hline 7. 20. Werksbevrediging & 4.40 & .640 \\
\hline 8. 21. Vervulde verwagtinge & 4.37 & .635 \\
\hline 9. 5. Die vermoë om jou begeertes te vervul & 4.33 & .688 \\
\hline 10. 9. Help ander om suksesvol te wees & 4.32 & .780 \\
\hline 11. 18. Volle waardering vir afgehandelde werk & 4.32 & .762 \\
\hline 12. 31. Erkenning & 4.27 & .821 \\
\hline $\begin{array}{l}\text { 13. 4. Die progressiewe realisering van waardige } \\
\text { doelwitte }\end{array}$ & 4.26 & .746 \\
\hline 14. 10. Goeie salaris & 4.12 & .781 \\
\hline 15. 12. Werksekuriteit & 4.06 & .886 \\
\hline 16. 14. Promosie & 4.03 & .763 \\
\hline 17. 15. 'n Gevoel van "in wees" op dinge & 3.90 & .930 \\
\hline 18. 13. Goeie werksvoorwaardes & 3.89 & .774 \\
\hline 19. 17. Lojaliteit teenoor medewerkers & 3.86 & .902 \\
\hline 20. 19. Taktvolle dissipline & 3.62 & .922 \\
\hline 21. 6. Rykdom & 3.56 & 1.014 \\
\hline 22. 24. Mag & 3.15 & .828 \\
\hline 23. 28. Prestige & 3.15 & .938 \\
\hline 24. 27. Weelde & 3.05 & .864 \\
\hline 25. 30. Materiële dinge & 3.03 & .799 \\
\hline 26. 16. Hulp met persoonlike probleme & 2.85 & .953 \\
\hline 27. 25. Roem & 2.75 & .894 \\
\hline
\end{tabular}


Sonder om spesifiek na al 27 komponente individueel te kyk, is dit voldoende om 'n paar opvallendes uit te sonder. Opvallend in die rangorde is die posisie wat geld (goeie salaris - posisie 14; rykdom - posisie 21; en weelde - posisie 24 ) inneem, teenoor die ander komponente. Vroeër is uitgewys dat geld/rykdom die algemeenste wanopvatting van sukses is. Dit ondersteun ook die genoemde gedagte dat indien jy 'n sekere punt bereik het, geld nie meer so belangrik is nie, maar wel sukses. Geld as komponent van sukses is minder belangrik as wat die algemene persepsie daarvan is.

Die stelling gemaak dat mag dikwels die indruk laat van sukses en dat mag soos geld van verbygaande aard is. Die rangorde plaas mag in posisie 26 uit 27. Daar kan hieruit moontlik afgelei word dat mag nie sukses tipeer soos tradisioneel aanvaar is nie.

Materiële dinge in posisie 25 beklemtoon dat dit waarna jy soek, nie met die uitbreiding van jou bates verkry kan word nie en dat hierdie tipe gedrag neig na kitsoplossings wat nie die toets van die tyd weerstaan nie.

Alhoewel roem verwerf kan word deur dit wat jy bereik en vermag, is dit in essensie nutteloos indien soos vermeld: “... goals that you are not authentically connected to are essentially meaningless ..." Jy kan een oggend ontwaak nadat jou doelwitte verwesenlik is en steeds ontkoppel van jouself voel. Die laaste plek wat roem inneem tipeer die gevoel van die respondente gemeet aan al die ander komponente dat roem 'n wêreldse standaard is wat aan jou gegee word indien jy die norm of standaard in die oë van die wêreld oorskry het.

Gesondheid is hoog aangeslaan in posisie 2. Dit is gestel dat positiewe gesondheid geassosieer word met 'n kapasiteit om die lewe te geniet, uitdagings te weerstaan en nie net die afwesigheid van siekte nie. Alhoewel gesondheid 'n belangrike komponent van sukses blyk te wees, is die moontlikheid nog daar dat ons onvervuld kan bly as ons nie die goddelike saad binne ons versorg nie.

Dit wil dus voorkom, anders as wat die literatuur voorhou, dat hierdie groep seniorbestuurders se keusepatroon nie die literatuur tendense en wanopvattings in sake soos geld; rykdom; mag; materialisme of gevoel navolg nie. 'n Voorkeur word gegee vir verrigting; gesondheid; interessante werk en om jou doel in die lewe te ken

\section{BESPREKING}

\section{Die tradisionele siening: Van buite-na-binne-sukses}

Volgens hierdie suksesbenadering glo mense dat sukses na hulle toe kom - nie deur harde werk, die gebruik van talente of vaardighede nie. Dit word verkry deur kans - deur die lotto te speel, op perdewedrenne wed of enige ander vorm van dobbel (Denney, 2002, p. 11). Sommige mense sal dalk een keer in hulle leeftyd hierdie geluk beleef, ander sal hulle lewensposisie vererger en tussen hoop en teleurstelling leef. Van buite-na-binne-sukses word ook beskryf as eenmalige sukses, seldsaam en omstandigheidsgebonde, jy moet daarvoor wag, jy is nie voorbereid daarop nie en ongemaklik daarmee (Maxwell, 1998, audio).

Die tradisionele komponente van sukses word vervolgens aangebied.

\section{Geld/Rykdom}

Volgens Maxwell (1997, p. 6) is die mees algemene wanopvatting oor sukses dat dit gelykstaande is aan rykdom. Rykdom bring nie sukses of tevredenheid nie. Maxwell (1997, p. 7) haal vir Aristotle Onassis aan dat hy gesê het: " after you reach a certain point, money becomes unimportant. What matters is success". Rykdom is ten beste van verbygaande aard. Geld kan nie geluk of liefde koop nie, die wêreld is vol ongelukkige miljoenêrs wat nie liefdevolle verhoudings kan behou nie (Gray, 1999, p. 9). 'n Verdere probleem met geld is dat dit wel kos vir jou kan koop, maar nie aptyt nie; geld kan klere koop, maar nie skoonheid nie; geld kan 'n mooi huis koop, maar nie noodwendig 'n gelukkige huis nie; geld kan boeke koop, maar nie wysheid nie; geld kan medisyne koop, maar nie gesondheid nie; geld kan iemand aan jou sy besorg, maar nie liefde nie; geld kan al die weelde van die wêreld koop, maar nie geluk nie.

Gray $(1999$, p. 9) sê dat hierdie wanpersepsie ons beroof van ons mag. Die mens kan sy lewe in die rigting van persoonlike sukses stuur as hy erken dat geld hom nie gelukkig kan maak nie, want dit is 'n illusie (Gray, 1999, p. 10).

\section{Mag}

Mag laat dikwels die indruk van sukses, maar is tydelik van aard (Maxwell, 1997: 9). Dit is 'n goeie toets vir 'n mens se integriteit en karakter, maar is op sigself nie positief of negatief nie, maar kan wel positief of negatief aangewend word (Maxwell, 1997:10). Mag is ook nie die bron van sekuriteit of sukses nie. Mag, net soos rykdom, is van verbygaande aard.

\section{Prestasie}

Volgens Maxwell (1997, p. 10) het mense bestemmingsiekte. Hulle glo as hulle iewers kan arriveer, 'n sekere posisie beklee, 'n doelwit behaal of selfs 'n verhouding kan hê met die regte persoon, sal hulle suksesvol wees. Maxwell (1997, p. 10) het sukses gedefinieer as 'n progressiewe realisering van ' $n$ doelwit wat die moeite werd is, maar het erken dat hierdie definisie kort van die merk geval het. Al sou jy jou doelwitte bereik en goed presteer, het jy nog geen waarborg dat jy sukses of tevredenheid sou beleef nie. Somtyds lê die geheim daarin om besig wees met 'n aktiwiteit en nie soseer by die einddoel nie. Vir Maxwell (1997, pp. 10-11) is sukses die reis en vir Waitley (1995, p. 251) die manier waarop gereis word.

\section{Materialisme}

Dit is soos wanneer iemand terug dink aan 'n tyd toe hy met sy hele hart, siel, en verstand iets wou gehad het. Eventueel wanneer daardie iets bekom is, kan hy die gevoel nie behou wat hy gedink het hy sou kry nie. Dit waarna gesoek is, word nie met die uitbreiding van bates verkry nie. Hierdie tipe gedrag neig na kitsoplossings wat nie die toets van die tyd weerstaan nie.

Ons is nie ongelukkig omdat ons nie het wat ons wil hê of nodig het nie, maar ons is ongelukkig omdat ons nog nie gekry het waarna ons soek nie - ons soek op die verkeerde plek (Williams, 2002, p. 17). Gray (1999, p. 20) sê dat ons na persoonlike sukses moet strewe, eerder as materiële sukses. Persoonlike sukses word verkry wanneer jy regtig goed voel oor jouself, jou verlede, jou hede en jou toekoms. Watter goed doen dit om materiële dinge te verwerf en steeds leeg en onvervuld te voel?

\section{Roem/Eer}

Die HAT (1992, p. 907) verwys na roem as 'n toestand om deur ander bewonder en geprys te word; om iemand lof of eer aan te doen. Roem of eer word van buite jouself deur ander aan jou toegeken. Dit is die wêreldse standaard waaraan sukses meer dikwels gemeet word en beteken dat jy die norm of standaard in die oë van die wêreld oorskry het, byvoorbeeld om 'n rekord te breek, die beste te wees met iets, om 'n fortuin te maak, wêreldvrede te bewerk (Carter-Scort, 2000, p XIII-XIV). Carter-Scott (2000, pp. 9-10) stel hierdie saak in perspektief: "Despite the fact that the world may applaud such efforts, however, goals that you are not authentically connected to are essentially meaningless...you may wake up one day having achieved your goals but feeling disconnected from yourself ". 


\section{Gesondheid}

Gesondheid volgens Bouchard is: “... 'n toestand met fisieke, sosiale en psigologiese dimensies elk op 'n kontinuum met positiewe en negatiewe pole. Positiewe gesondheid word geassosieer met 'n kapasiteit om die lewe te geniet en uitdagings te weerstaan, dit is nie net die afwesigheid van siekte nie. Negatiewe gesondheid word geassosieer met morbiditeit en in ekstreme situasies met mortaliteit" (Dryer, 1996, p. 5).

Elke mens verwag om meer uit die lewe te haal, die gehalte en die duur daarvan te verhoog (Serfontein, 2001, p. 11). Volgens Serfontein (2001, p. 11) het ' $n$ nuwe fokus op dieet die afgelope twintig jaar ons laat besef watter voordele afsonderlike voedingstowwe wat op 'n onkonvensionele manier gebruik word, kan hê om die lewe te help verleng. Buiten dieet, is denkpatrone en gesindheid twee ander belangrike aspekte: "Of ons daarin slaag om 'n lewensverwagting van oor die 100 jaar te bereik, sal hoofsaaklik deur ons denkpatrone bepaal word. Hoe ons dink, bepaal hoe ons optree en hoe ons optree, bepaal baie aspekte van ons lewe, waaronder die gehalte daarvan" (Serfontein, 2001, pp. 12-13). 'n Derde belangrike aspek is geestesprosesse: "Ons geestesprosesse is hoogs afhanklik van ons fisieke welsyn...'n gesonde gees kan net in 'n gesonde liggaam leef...produktiewe, inspirerende en vernuwende gedagtes kan nie ontwikkel in 'n liggaam wat wanfunksioneer nie. 'n Beter lewensgehalte en hoër lewensverwagting sal net werklikheid word as ons denkpatrone stelselmatig verander, maar dit kan net gebeur as ons liggaam en brein fisiek daarop ingestel is" (2001, p. 15).

Gesondheid is nie sukses op sigself nie, maar ' $n$ belangrike deel daarvan. Chopra (1996, p. 2) voel dat selfs met die ervaring van goeie gesondheid ons steeds onvervuld kan bly as ons nie die goddelike saad binne ons versorg nie.

\section{'n Spesiale gevoel en geluk}

Nog ' $n$ wanpersepsie is dat 'n mens sukses gevind het wanneer hy suksesvol of gelukkig voel. Donald Trump (in Maxwell, 1997, p. 8 ) het gesê: "The real measure of success is how happy you are". Hierdie oortuiging onderstreep dat mense sukses vereenselwig met dit wat hulle nie het nie. Hier teenoor beweer Maxwell (1997, p. 8) dat die voortdurende soeke na geluk, die primêre rede is waarom mense so mistroostig is. As jy geluk jou doel maak, is jy amper seker van mislukking. Ook Williams (2002, p. 14) deel hierdie gedagte as hy verduidelik dat dit ' $n$ fout is om te glo dat sukses ons gelukkig sal maak of die pyn sal wegneem, want sukses sal alleenlik beklemtoon wat ons reeds voel en dink. 'n Mens kan nie op geluk vertrou om sukses te meet nie (Maxwell, 1997, p. 8).

Maar wat is geluk? Volgens die Merriam-Webster dictionary (http://www.m-w.com/cgi-bin/dictionary) dateer die woord 'geluk' terug na die vyftiende eeu en het te doen met welvaart en voorspoed; dit is 'n staat van welstand en tevredenheid. Die woord 'geluk' het ook noue verband met die woord 'joy', 'n selfstandige naamwoord en middel-Engelse woord afkomstig van die oud-Franse woord 'joie' en van Latyn 'gaudia', asook Grieks 'gethein' wat 'to rejoice' beteken. Vanaf die dertiende eeu is hierdie woord gebruik om emosie te verwek as gevolg van welstand, sukses, goeie geluk of selfs die vooruitsig om iets te besit wat jy begeer het. Dit is 'n staat van geluk en die bron of oorsaak van genot. Maar wat is die oorsake wat daartoe lei dat mense gelukkig is? Geluk word volgens Denny $(2002$, p. 8) bereik op drie maniere:

- Deur uit te sien na iets. Dink net hoe jy sal reageer as jy ' $n$ nuwe motor wil koop. Die opgewondenheid bou binne jou op. Die dag as jy die motor in ontvangs neem, is alles nuut. $\mathrm{Na}$ 'n paar maande verander jou gesindheid teenoor die motor. Jy vind dat die plesier nie gekom het deur die besit van die motor nie, maar deur uit te sien om die motor te besit. Hierdie beginsel kan aangewend word vir enigiets wat besit of bereik wil word.
- Deur mededeelsaam te wees. ' $n$ Vreugde wat gedeel word is 'n vreugde wat verdubbel word en 'n bekommernis wat gedeel word is bekommernis wat gehalveer word. Geluk lê daarin om met ander te deel, 'n gee gesindheid.

- Om iemand anders gelukkig te maak. Ware geluk lê juis in die gee vir 'n ander, eerder as die ontvang.

Denny (2002, p. 11) motiveer bogenoemde drie riglyne vir geluk deur te sê dat dié volle verstaan van 'geluk' een van die hoofareas is waarop ons moet konsentreer. Dit word nie in die skole, universiteite of van ouer na kind oorgedra nie. So baie wat na sukses soek, soek in die verkeerde rigting. Geluk, soos sukses, is nie 'n doel op sigself wat nagejaag kan word nie, maar 'n neweproduk van die resultaat van dit wat nagejaag word.

Om geluk te vind moet ons ' $n$ inwaartse reis begin om terug te vind en te onthou wie ons regtig is (Gray, 1999, p. 23). Deur inwaarts te kyk, ontdek ons dat geluk, mag, vrede en liefde reeds daar teenwoordig is. Hierdie kwaliteite is wie ons regtig is.

\section{Van binne-na-buite-sukses}

Van binne-na-buite-sukses is ' $n$ benadering waar jy nader aan sukses beweeg. Hierdie vorm van sukses gebeur meer dikwels, is 'n keuse, jy neem die inisiatief, dit is voortdurende sukses, jy is meer voorbereid vir hierdie vorm van sukses en jy is ook meer gemaklik daaroor omdat jy daarvoor gewerk het (Maxwell, audio: Statements about success). Jou selfbeeld bepaal jou vlak van volgehoue sukses omdat jy ook nooit verder kan groei as waartoe jy glo jy in staat is nie (Maxwell, audio, Statements about success).

\section{Sukses hang van jou verwagtinge af}

Mayer (1999, p. 5) sê dat die hele saak, rondom of 'n persoon suksesvol is, baie kompleks is omdat die resultate afhanklik is van 'n persoon se lang- en korttermyn verwagtinge. Bykomende by talente, vaardighede en opleiding is daar veel meer faktore wat binne of buite jou beheer is. Indien iemand werk vir ses A simbole en in een vak ' $n$ B simbool behaal, sou die meeste mense reken dat hy suksesvol was. Maar die persoon kan mislukking ervaar as die eindresultaat gemeet word aan die aanvanklike verwagting.

Die bepalende faktor in enige saak om 'n sukses te wees, is jou verwagtinge. Die kriteria waaraan ons ons sukses meet en beoordeel, moet vooraf bekend wees. Min mense is werklik $100 \%$ suksesvol in alles wat hulle doen. Jy moet jou beste doen, uit jou ervaringe leer en die kennis wat jy versamel het, neem sodat jy dit die volgende keer nog beter kan doen (Mayer, 1994, p. 4). Sukses, volgens Mayer (1999, p. 10), moet gesien word volgens drie kriteria:

- Sien sukses in sekere tydlyne: moment na moment, dag tot dag, maand tot maand, jaar na jaar of oor jou hele lewe (Mayer, 1999, p. 10).

- Het jy jou verwagtinge oorweeg voordat jy begin het (Mayer, 1999, p. 10)?

- Is hierdie verwagtings jou eie, jou ouers of dalk die wêreld s'n (Mayer, 1999, p. 10)?

Sukses versus vervulling

Carter-Scott (2000, p. XIII) sê dat alhoewel sukses vir verskillende mense verskillende dinge beteken, is dit wel duidelik dat daar 'n diepe behoefte bestaan by talle mense wat onderliggend werk deur hulle visie, drome en doelwitte aan vervulling. Volgens die Merriam-Webster woordeboek (http://www.m-w.co.com/cgi-bin/dictionary) beteken vervulling: om vol te maak (vul); om in effek te bring; om vereistes na te kom; om tot 'n einde te bring; om te bevredig; om te omvorm na die realiteit, maar ook om die volle potensiaal te ontwikkel van iets. Sukses het 'n eksterne konnotasie en vervulling ' $n$ interne konnotasie. Jy alleen kan jouself as vervuld ag, maar sukses is iets wat aan jou toegedig word van buite jouself. Hierdie standaarde waaraan sukses 
gemeet word, is die wêreld se standaarde en by implikasie beteken dit dat jy die norm of standaard in die oë van die wêreld oorskry het, of dat jy jou drome gerealiseer het (Carter-Scott, 2000, p. XIV).

Tom en Natalie Rusk (1988, pp. 194-195) sluit by hierdie gedagtes aan: "Success is a necessary ingredient for fulfillment in work. And fulfillment in work is necessary for an overall sense of wellbeing...by definition, success provides money, prestige, fame and influence. Success can also give you a sense of accomplishment and confidence in a particular ability ... success is not fulfillment. Success alone is never enough. Many people are successful; far fewer feel fulfilled".

Monroe (1992, pp. 140-141) voer aan dat ons as 'n gemeenskap sukses met vervulling verwar en dat sukses alleen gedefinieer kan word deur doel ("purpose") en gemeet kan word deur gehoorsaamheid aan daardie doel. Sukses is nie wat jy gedoen het vergeleke met wat ander gedoen het nie, maar wel wat jy gedoen het vergeleke met wat jy moes doen (Monroe, 1992, p. 142).

'Doel' ("purpose") is die sleutel en die fondasie vir sukses (Monroe, 1992, p. 142). Dit is die ware bron van vervulling en die enigste ware meting van die lewe (Monroe, 1992, p. 142). 'Doel' is nie om 'n goeie ding te doen nie, maar wel om die regte ding te doen; dit word die verskil om besig te wees en om effektief te leef (Monroe, 1992, p. 143).

\section{Sukses vanuit 'n Persoonlike en Professionele Leierskap Perspektief}

Volgens 'n PPL-perspektief besef mense dat hulle sukses van hulself afhang om op 'n proaktiewe wyse, gegrond op karakter, beginsels en waardes in balans met alle lewensdimensies, hulle lewensdoel te verwesenlik deur potensiaal te maksimaliseer en te realiseer. Sodoende kan 'n mens met al sy talente, vaardighede en gawes nie net hierdie bates vir homself/haarself hou nie, maar ook aanwend vir 'n groter doel as net sy/haar eie: om ' $n$ nalatenskap daar te stel en iemand anders te help om suksesvol te wees.

Verhoudings speel 'n sentrale rol in PPL-perspektief in terme van sukses. Navorsing toon dat verhoudings die sleutel is in gesondheid, voorspoed, geluk, hoop en feitlik enigiets van waarde (Ziglar, 1998, p. 3).

PPL kyk holisties na die mens in al sy dimensies. Sukses moet in hierdie dimensies gebalanseer word om waarlik sukses te kan beleef. Van binne-na-buite-sukses moet eers realiseer en gebalanseer word met van buite-na-binne-sukses. Van binne-na-buite-sukses (karakter, beginsels, waardes, doel, potensiaal, selftransendering, wie ek is, ens.) is die wortels wat die boom stewig anker, voed en die groei van die boom is die resultaat hiervan. Die vrugtetakke en blare van die boom is die van buite-na-binne-sukses (geld, prestasie, eer, lof, erkenning, gevoel, mag, verrigting, ens.). Die sleutel tot sukses is balans in al die mens se dimensies. Volgens Henning (2001, p. 40) is daar stappe vanuit 'n Persoonlike en Professionele Leierskapsperspektief wat 'n mens kan neem om lewensbalans te skep:

Fisieke dimensie - Hou jou liggaam in stand en versorg jou liggaam deur gesond te eet, gereelde oefening, rus en ontspanning asook die vermyding van destruktiewe gewoontes soos rook en alkoholmisbruik.

Emosionele dimensie - Neem eienaarskap van positiewe (liefde, omgee en lag) en negatiewe emosies (kwaad, aggressie, woede) en streef na positiewe emosies. Word bewus van jou emosionele aksies, verstaan die onderliggende boodskap van daardie emosies en laat tyd en ruimte om 'n gepaste emosionele reaksie. Sodoende kan jy emosies in jouself bestuur. 'n Mens bly sodoende in beheer van sy eie emosies met eienaarskap en verantwoordelikheid.
Sosiale dimensie - Belê in ander mense, oorskry jouself, doen goed aan ander, ontwikkel 'n oorvloedshouding en voeg elke dag waarde in iemand se lewe toe. Maak seker dat jy gehaltetyd met diegene deurbring wat vir jou belangrik is en vir wie jy omgee. Kommunikeer betekenisvol met mense met wie jy in ' $n$ verhouding staan, hetsy in jou gesin; huwelik; groter familie; vriendskap of werkomgewing.

Geestelike dimensie - Werk aan geestelike verdieping - Lewe doelgerig; luister na mooi musiek; bid of mediteer; ontwikkel 'n dankbaarheidshouding; lees inspirerende of motiverende leesstof; voeg elke dag waarde aan iemand toe. Leef jou drome en strek jouself om jou potensiaal te realiseer.

Intellektuele dimensie - 'n Mens moet nuuskierig bly om meer te wil weet - 'n ewige leerder. Konstante en nimmereindigende verbetering begin hier waar jy meer lees, met ingeligte persone gesels, verdere opleiding deurmaak, kursusse bywoon, selfhelpmaterial te bestudeer, seminare bywoon, ensovoorts.

\section{Gevolgtrekking}

Die probleem wat aan die begin van artikel studie gestel is, naamlik dat daar onduidelikheid in die literatuur bestaan en ook in die praktyk oor wat presies die belewenis van sukses by mense is, asook dat mense dikwels ' $n$ dissonans ervaar tussen uiterlike sukses en innerlike vervulling, blyk vanuit die bespreking geregverdig te wees.

Belangrike komponente wat nodig is om sukses te beleef, is uit die literatuur geïdentifiseer en in die praktyk getoets om 'n interne- (intrinsieke faktor) en 'n eksterne- (ekstrinsieke faktor) van suksesbelewing te stel. Albei hierdie faktore moet aandag geniet om op 'n gebalanseerde wyse sukses te kan beleef. Die aksie-handeling staan voorop om sukses te inisieer. Sukses, in een area van jou lewe beteken nie algehele sukses nie. Balans in al die verskillende lewensdimensies waarin die mens funksioneer, is noodsaaklik. Die mens moet weet wie hy is, waar hy met homself staan, wat hy graag wil doen en wees, asook dienooreenkomstige stappe doen om daar uit te kom. Aangesien al hierdie aspekte op die beginsels van Persoonlike en Professionele Leierskap berus, kan die gevolgtrekking gemaak word dat Persoonlike en Professionele Leierskap 'n belangrike bydrae kan lewer om sukses op 'n gebalanseerde wyse te kan beleef.

\section{PERSOONLIKE EN PROFESSIONELE LEIERSKAP RIGLYNE}

Daar verskillende stappe vanuit ' $n$ Persoonlike en Professionele Leierskapsperspektief wat 'n mens kan neem om lewensbalans ten opsigte van suksesbelewing te skep:

- Word bewus van wanbalans in jou lewe en dat jy dit kan regstel en nuwe balans kan skep.

- Jy kan self keuses maak en verantwoordelikheid vir jou eie lewe aanvaar.

- Klaar jou waardes uit. Bly getrou aan jouself, aan dit wat vir jou belangrik is en betekenis aan jou lewe gee. Waardes sal jou in staat stel om jou prioriteite te bepaal en sodoende kongruensie bewerk tussen wat ek sê en doen.

- Sukses as balans in terme van jou lewensdimensies kan as riglyn dien om nagevolg te word.

Dis belangrik dat jou suksesbeskouing en die belewing daarvan kongruent moet wees om vervulling te kan beleef. Hierdie belewing word moontlik as jou sukses ooreenkom met wie jy is, waarheen jy op pad is en hoekom jy daarheen op pad is. Die realisering van jou potensiaal, die nastrewing van jou doelwitte vanuit jou waardes, deur middel van jou drome, moet getrou wees aan jou karakter en beginsels en tot diens van jou medemens. Die strewe om waarde toe te voeg tot die mense rondom jou, is ' $n$ verdere voorvereiste om vervulling te beleef. 
Die mens se eerste taak is om sy unieke gawes te ontdek deur dit te vind wat vir hom vreugde verskaf. Wanneer dit gebeur, ontdek hy sy energie en begin hy om sy eie niche in die lewe te skep. Hy vind dit as hy dit ontdek wat natuurlik na hom toe kom. Hy vind ongetapte krag van wil en innerlike mag wat vloei van sy gees, wat tot uitdrukking kom wanneer hy dit wat uniek en waardevol is, tot uitdrukking laat kom. Om die lewe te bou kompleet met innerlike satisfaksie, persoonlike sin en erkenning, moet hy die werk skep waarvoor hy lief is. Op hierdie wyse kan die mens 'n manier skep om 'n inkomste te verdien deur te doen waarvoor hy lief is, terwyl hy ander mense dien op 'n outentieke wyse.

\section{VERWYSINGS}

Brewis, F.M. (2000). Die mens as faktor in suksesvolle organisasies: 'n Persoonlike en Professionele en Leierskapsperspektief. Ongepubliseerde Magisteressay, Randse Afrikaanse Universiteit, Johannesburg.

Carter-Scott, C. (2000). If Success Is a Game, these are the Rules. London: Ebury Press.

Cashman, K. (2000). Leadership From The Inside Out. Provo: Executive Publishing.

Chopra, D. (1996). The Seven Spiritual Laws of Success. London: Bantam Press Ltd.

Covey, SR. (1992). The Seven Habits of Highly Effective People. London: Simon \& Schuster Ltd.

Denny, R. (2002). Success for yourself. London: Clays Ltd, St Ives plc.

Dryer, L.I. (1996). Totale Welstand 'n Begripsomskrywing. Potchefstroom: PU.
Gray, J. (1999). How to get what you want and want what you have a practical guide to personal success. London: Random House.

Henning, W. (2001). 'n Persoonlike en Professionele Leierskapsperspektief op die skep en handhawing van lewensbalans. Ongepubliseerde Magisteressay, Randse Afrikaanse Universiteit, Johannesburg.

Maxwell, J.C. (Oktober 1998). Audio Casette - Enjoy. Statements about success. Kaapstad: Meridien Marketing.

Maxwell, J.C. (1997). The Success Journey. Atlanta: Thomas Nelson Publishers.

Mayer, J. (1999). Success is a journey: 7 Steps to achieving in the business of life. New York: McGraw-Hill.

Mirriam, Webster's Collegiate Dictionary. www.m-w.com/cgibin/dictionary.

Monroe, M. (1992). In pursuit of purpose. Shippensbury: Destiny Image Publishers, Inc.

Rusk, T. \& Rusk, N. (1998). Coach Yourself to Success. London: Thorsons.

Schoonees, P.C.; Swanepoel, C.J.; Du Toit, S.J.; Booysen, C.M. (1965). Verklarende Handwoordeboek van die Afrikaanse Taal (HAT). Kaapstad: Perskor.

Serfontein, W. ( 2001). Geneesende Voeding - Omskep jou lewe. Kaapstad: Tafelberg-Uitgewers.

Smith, D.P.J. (2001). Persoonlike en Professionele Leierskap. Klasaantekeninge. Johannesburg: RAU.

Smith, D.P.J. (1993). Navorsingsontwerp en metodes van navorsing. Johannesburg: RAU.

Waitley, D. (1995). Empires of the Mind. Nicholas Brealey Publishing Ltd.

Williams, N. (2002). Unconditional Success. London: Bantam Press.

Ziglar, Z. (1998). Success for Dummies. Foster City: IDG Books Worldwide Inc. 